\title{
An Unusual Case of Marginal Zone B-Cell Lymphoma Arising in the Breast - Its Diagnosis and the Role of Radiotherapy in its Management
}

\author{
Kathy Rock Guhan Rangaswamy Siobhra O'Sullivan Jerome Coffey
}

Department of Radiation Oncology, St. Luke's Hospital, Rathgar, Dublin 6, Ireland

\section{Keywords}

Marginal zone B-cell lymphoma - Breast .

Non-Hodgkin's lymphoma · Involved field radiotherapy

\section{Summary}

Background: Primary lymphoma of the breast accounts for $0.04-0.5 \%$ of all breast malignancies and approximately $1 \%$ of all extranodal lymphomas. For stage IE node-negative disease, involved field radiotherapy is recommended except for very young women in whom the risk of breast cancer is a concern. The rate of complete response for limited stage extranodal marginal B-cell lymphoma is in excess of $90 \%$. Case Report: We report the case of a 62-year-old lady who presented with a unilateral painless palpable right breast lump. She subsequently underwent a trucut biopsy of the lesion. The histology revealed a low-grade B-cell non-Hodgkin's Iymphoma (NHL). Immunohistochemistry showed that more than $95 \%$ of the cells were $B$ cells which were $C D$ $20+/ C D 45+$ and BC L6+. This confirmed the diagnosis of marginal zone lymphoma. Staging work-up was negative for distant metastases. Serum alkaline phosphatase and lactate dehydrogenase were normal. The patient had no ' $B$ ' symptoms. Her final diagnosis was clinical stage IAE NHL, and she was referred for curative radiotherapy. Conclusion: Radiation treatment is a safe and extremely effective modality of treatment for early stage I marginal zone B-cell lymphomas of the breast.

\author{
Schlüsselwörter \\ Marginalzonen-B-Zell-Lymphom · Brust . \\ Non-Hodgkin-Lymphom · Involved-Field-Radiotherapie
}

\section{Zusammenfassung}

Hintergrund: Primäre Lymphome der Brust machen $0.04-0.5 \%$ aller Mammatumoren und ungefähr $1 \%$ aller extranodalen Lymphome aus. Für Patientinnen mit Tumoren im Stadium IE und ohne Lymphknotenbefall wird die Involved-Field-Radiotherapie empfohlen, mit Ausnahme von sehr jungen Frauen, bei denen das Mammakarzinomrisiko von Bedeutung ist. Extranodale Marginalzonen-B-Zell-Lymphome im Frühstadium zeigen ein komplettes Ansprechen in mehr als $90 \%$ der Fälle. Fallbericht: Wir berichten von einer 62-jährigen Patientin, die mit einem unilateralen, schmerzlosen, palpablen Knoten in der rechten Brust vorstellig wurde. Die histologische Untersuchung einer Trucut-Biopsie der Läsion ergab ein niedriggradiges B-Zell-Non-Hodgkin-Lymphom (NHL). Die immunhistochemische Untersuchung zeigte, dass es sich bei mehr als 95\% der Zellen um BZellen mit den folgenden Merkmalen handelte: CD 20+/ CD 45+ und BC L6+. Dies bestätigte die Diagnose eines Marginalzonen-Lymphoms. Das Staging ergab keine Fernmetastasen. Die Serumspiegel der alkalischen Phosphatase und Laktatdehydrogenase waren normal. Die Patientin zeigte keine ' $\mathrm{B}$ '-Symptomatik; die Enddiagnose war IAE-NHL im klinischen Stadium, und sie wurde zur kurativen radiotherapeutischen Behandlung überwiesen. Schlussfolgerung: Radiotherapie ist eine sichere und extrem effektive Behandlungsmodalität bei Marginalzonen-B-Zell-Lymphomen der Brust im frühen Stadium I.

\section{KARGER \\ Fax +497614520714 \\ Information@Karger.de}

www.karger.com (c) 2011 S. Karger GmbH, Freiburg

$1661-3791 / 11 / 0065-0391 \$ 38.00 / 0$

Accessible online at:

www.karger.com/brc
Dr. Kathy Rock

St. Luke's Hospital

Rathgar, Dublin 6, Ireland

Tel. +353 14065-000/+353 86 8420854, Fax -222

kathy.rock@slh.ie 


\section{Introduction}

Primary lymphoma of the breast is extremely rare. It accounts for $0.04-0.5 \%$ of all breast malignancies and approximately $1 \%$ of all extranodal lymphomas [1]. The vast majority present as a unilateral painless breast mass in postmenopausal women (average age at diagnosis is 55-60 years). The vast majority of primary breast lymphomas are non-Hodgkin's lymphomas (NHL) and are most commonly B-cell subtypes. We herein present a case of NHL of the breast.

\section{Case Report}

We report the case of a 62-year-old lady who was referred by her General Practitioner to a tertiary referral specialist breast unit with a unilateral painless palpable right breast lump. Clinical examination revealed a single palpable mass in the upper inner quadrant with no regional associated adenopathy. Her physical examination was otherwise unremarkable. Her Eastern Cooperative Oncology Group (ECOG) performance status was $0-1$. In her past medical history, she had a right hemicolectomy for a caecal mass 1 year previous to this presentation. The histology at that time revealed reactive lymphoid tissue only, with no evidence of malignancy. Her initial radiological work-up for this new breast mass included a mammogram and an ultrasound. She subsequently underwent a Trucut biopsy of the lesion. The histology revealed a low grade B-cell NHL. Immunohistochemistry showed that more than $95 \%$ of the cells were B cells which were CD 20+/CD 45+ and BCL 6+. This confirmed the diagnosis of marginal zone lymphoma (MALT lymphoma). The patient subsequently had a fine needle aspirate of a right axillary node, which showed no evidence of any malignancy. Her staging work-up included a computed tomography (CT) scan of the thorax, abdomen and pelvis, which revealed no other sites of disease. The serum alkaline phosphatase and lactate dehydrogenase (LDH) levels were within normal limits, and she had no 'B' symptoms at the time of presentation. Her final clinical diagnosis was stage IAE NHL. Her case was discussed at a multidisciplinary meeting, and subsequently she was referred to St. Luke's Hospital for radiotherapy with radical (curative) intent. A planning CT was preformed, and a 2-field tangential breast plan was generated. The radiotherapy plan was discussed at a consultant-specific radiotherapy planning meeting, and a dose schedule of 30 Gy delivered in 15 fractions was agreed upon. The patient had a clinical reduction in the size of her lesion while receiving radiotherapy which was tolerated extremely well with no acute toxicities. She is due for routine follow-up 6 weeks post completion of radiotherapy. She will be seen at periodic intervals of 3 months for the first year to monitor her for treatment complications and assess for possible relapse.

\section{Discussion}

Primary lymphoma of the breast is extremely rare. The average age at diagnosis is 55-60 years. The right breast is more commonly involved (as was the case in this presentation) than the left, the reason for this is unknown. In just under half of all cases, ipsilateral axillary lymphadenopathy is present. There is some evidence that the increased use of mammographic screening for breast carcinoma is leading to incidental detection of breast lymphomas [2]. The vast majority of primary breast lymphomas are NHL and are most commonly
B-cell subtypes. Up to $50 \%$ are diffuse large B-cell lymphoma, and indolent histological types such as extranodal marginal zone lymphomas, as in this case, occur less commonly.

\section{Staging}

The Ann Arbor staging system is commonly used for staging as with other lymphomas. The staging of this disease should start with a careful history and clinical examination. Also basic blood samples should be taken and in particular analysed for serum $\mathrm{LDH}$ followed by appropriate radiological imaging (CT thorax, abdomen, and pelvis). A bone marrow aspiration and biopsy should be carried out in patients with multifocal disease. It should be remembered that approximately $10 \%$ of breast cases are bilateral, and the assessment of the contralateral breast is essential. The overall clinical stage in this case was of IE, that is disease limited to the breast only. Involvement of ipsilateral axillary lymph nodes is stage IIE.

\section{Treatment}

In general, the treatment of primary breast lymphomas follows treatment recommendations for lymphomas of the same stage and histology in other locations. Surgical options such as full mastectomy or wide local excision do not appear to reduce the risk of local recurrence or improve survival [3]. For stage IE node-negative disease, as was the case in this report, local radiation alone, i.e. involved field radiotherapy (IFRT), is recommended except for very young women in whom the risk of breast cancer is a concern. IFRT with 20-30 Gy is the primary therapy for most cases of limited stage extranodal marginal zone B-cell lymphoma. With this approach, rates of complete response and local control are greater than 90\% [4]. Adjuvant rituximab or chemotherapy in stage IE extranodal indolent NHL are not recommended. Stage IIE (node-positive) and advanced disease are generally treated with systemic chemotherapy, i.e. rituximab monotherapy or observation. Some patients who have low bulk disease $(<10 \mathrm{~cm})$, outer quadrant tumours, and ipsilateral axillary nodal involvement may be treated with radiation treatment alone as an alternative.

\section{Prognosis}

The prognosis of NHL is dependent upon histological type and clinical stage. Poor prognostic indicators include age over 60, stage II rather than I disease, raised LDH (more than 1.5 times the upper limit of normal), an ECOG score $\geq 2$, and more than 1 extranodal site of disease. The international prognostic index [5] is a useful tool in predicting the prognosis. 1 point is given for each of the following characteristics for a total score ranging from 0 to 5 : i) age $>60$; ii) serum $\mathrm{LDH}$ above normal; iii) ECOG performance status $\geq 2$; iv) Ann Arbor stage III or IV; v) number of extranodal disease sites $>1$. The rates of complete response and local response with IFRT for limited stage extranodal marginal B-cell lymphoma are in excess of $90 \%$ (table 1 ). 
Table 1. Prognostic scoring of non-Hodgkin's lymphoma

\begin{tabular}{lllll}
\hline Risk & IPI score & $\begin{array}{l}\text { Com- } \\
\text { plete re- } \\
\text { sponse } \\
\text { rate, } \%\end{array}$ & $\begin{array}{l}\text { Relapse- } \\
\text { free 5-year } \\
\text { survival, } \\
\%\end{array}$ & $\begin{array}{l}\text { Overall } \\
5 \text {-year } \\
\text { survival, } \\
\%\end{array}$ \\
\hline Low & $0-1$ & 87 & 70 & 73 \\
Low/intermediate & 2 & 67 & 50 & 51 \\
High/intermediate & 3 & 55 & 49 & 43 \\
High & $>4$ & 44 & 40 & 26 \\
\hline
\end{tabular}

IPI = International prognostic index.

\section{Conclusion}

Overall, marginal zone B-cell lymphomas display an indolent disease biology. A high local control rate and low incidence of toxicity with moderate dose radiotherapy (25-30 Gy) are seen. Radiation treatment is a safe and extremely effective modality of treatment for early stage I marginal zone B-cell lymphomas of the breast.

\section{Disclosure Statement}

The authors declare no conflict of interest.

\section{References}

1 Brogi E, Harris NL: Lymphomas of the breast: pathology and clinical behaviour. Semin Oncol 1999;26:357-64. Review.

2 Domchek SM, Hecht JL, Fleming MD, et al.: Lymphomas of the breast: primary and secondary involvement. Cancer 2002;94:6-13.
Jennings WC, Baker RS, Murray SS, et al.: Primary breast lymphoma: the role of mastectomy and the importance of lymph node status. Ann Surg 2007;245:784-9.

4 Tsang RW, Gospolarowicz MK, Pintilie M, et al.: Localized mucosa - associated lymphoid tissue lymphoma treated with radiation therapy has excellent clinical outcome. J Clin Oncol 2003; 21:4157-64.

P

5 No authors listed: A predictive model for aggressive non-Hodgkin's lymphoma. The International Non-Hodgkin's Lymphoma Prognostic Factors Project. N Engl J Med 1993; 329:987-94. 